\title{
MAKNA DAN SIMBOL DALAM UPAGARA ADAT PERKAWINAN SUNDA DI KABUPATEN BANDUNG
}

\author{
Oleh Enden Irma Rachmawaty
}

Balai Pelestarian Sejarah dan Nilai Tradisional Bandung Jln. Cinambo No. 136 Ujungberung Bandung

\begin{abstract}
Abstrak
Masyarakat Sunda memiliki budaya tradisional yang beragam. Walaupun keberadaannya tidak sama, apabila kita lihat nilai filosofinya, semua memiliki nilai filosofi yang cukup tingggi. Salah satunya ialah upacara adat perkawinan. Setiap acara dalam adat perkawinan tersebut memiliki simbol dan makna sebagai lambang kehidupan kebudayaan masyarakat pemiliknya. Penelitian ini bertujuan mengungkap Upacara Adat Perkawinan Sunda yang sampai saat ini masih tetap lestari. Penelitian upacara adat ini bersifat deskriptif dengan metode kualitatif. Upacara adat ini terdiri atas kegiatan sebelum pernikahan, saat pelaksanaan pernikahan dan setelah pernikahan. Dalam kegiatan sebelum pernikahan ada beberapa upacara di antaranya neundeun omong, ngalamar (minang), nyangcang (mengikat calon pengantin), narikan (menentukan kepastian), dan seserahan. Saat pelaksanaan pernikahan terdiri atas akad nikah dan sungkem. Setelah pelaksanaan pernikahan terdapat upacara sawer, nincak endog dan huap lingkung. Semua rangkaian upacara tersebut memiliki simbol dan makna tersendiri.
\end{abstract}

Kata kunci: upacara, perkawinan adat Sunda

\section{Abstract}

The Sundanese society has various traditional cultures. All of them have very high philosophical values, although some differences exist. Wedding ceremony is one of them. Every steps in Sundanese wedding ceremony has meanings and symbols of their cultural life. This research is a descriptive study concerning Sundanese wedding ceremony using qualitative method. The ceremony consists of activities that are implented before, during, and after the wedding. Before the wedding there are neundeun omong (a kind of promise given by a man to the family of the bride-to-be that he would marry a woman of their family), ngalamar (to propose), nyangcang (to engage), narikan (to confirm), and seserahan (gifts from the bridegroom to the bride 
symbolizing his responsibility as husband in their marriage). During the wedding there are akad nikah (the wedding pledge) and sungkem (giving tribute to the parents and the elders). Lastly, after the wedding they have sawer (pouring rice and coins to the bride and the bridegroom symbolizing their fortune in the future), nincak endog and huap lingkung.

Keywords: ceremony, wedding, Sundanese tradition

\section{A. PENDAHULUAN}

Masyarakat Sunda termasuk masyarakat yang memiliki budaya tradisional yang cukup banyak. Budaya-budaya tersebut hingga saat ini keberadaannya masih bertahan, tetapi ada pula yang hampir punah. Walaupun keberadaannya tidak sama, apabila kita lihat nilai filosofinya, semuanya memiliki nilai filosofi yang cukup tingggi. Hal ini menandakan bahwa pencipta budaya pada zaman dahulu, tidak hanya menciptakannya dengan secara asal-asalan, tetapi memiliki visi yang mengandung nilai-nilai filosofi yang cukup tinggi.

Upacara adat perkawinan merupakan salah satu budaya yang sampai saat ini, keberadaanya masih tetap dipertahankan. Dalam upacara adat perkawinan ini terdiri atas serangkaian acara yang satu dengan lainnya saling berkaitan. Setiap acara dalam adat perkawinan tersebut memiliki simbol dan makna sebagai lambang kehidupan kebudayaan masyarakat pemiliknya. Misalnya dalam upacara adat perkawinan ini ada salah satu bagian acara huap lingkung (makan bersama), simbol dari budaya ini mengandung makna bahwa suami isteri memberi tidak terbatas dengan tulus dan ikhlas sepenuh hati. Masih banyak lagi bagian-bagian budaya dalam upacara adat perkawinan ini yang memiliki makna dan simbol yang berhubungan dengan kehidupan masyarakat. Namun, gambaran semacam ini belum banyak yang mengungkap secara menyeluruh.

Upacara adat perkawinan Sunda ini berkaitan erat dengan rangkaian budaya dan mengungkap simbol dari rangkaian budaya yang biasa dilaksanakan dalam upacara adat perkawinan Sunda. Upacara adat perkawinan ini adalah salah satu upacara adat tradisional masyarakat di Jawa Barat yang sampai saat ini masih tetap dipertahankan. Upacara adat ini, memiliki aturan yang sudah baku. Aturan itu mencakup keseluruhan bagian dalam pelaksanaan kegiatan upacara. Keberadaannya selain masih kokoh juga mengandung nilai falsafah yang cukup tinggi.

\section{B. HASIL DAN BAHASAN}

Adat perkawinan ini merupakan rangkaian acara yang biasa dilaksanakan dalamrangkamelangsungkan perkawinan menurut tata cara adat tradisional yang sudah berjalan berabad-abad. Tata cara perkawinan Sunda biasanya mulai dari acara sebelum upacara pernikahan/ perkawinan, saat akad nikah, dan setelah upacara perkawinan. Tata cara sebelum perkawinan terdiri atas nanyaan (meminang) dan nyangcang (mengikat calon pengantin), narikan (menentukan kepastian), dan nyindekkeun (menentukan waktu). 
Seminggu sebelum acara seserahan, di tempat pengantin diadakan tutunggulan yang disebut ngaleunggeuh, yaitu memberi isyarat kepada tetangga bahwa seminggu lagi akan ada tutunggulan, yaitu menumbuk padi secara beramai-ramai yang berasnya akan dimasak pada waktu acara pernikahan. Seserahan merupakan acara penyerahan calon mempelai pria beserta barang bawaannya yang akan diserahkan kepada calon mempelai wanita, yang dilaksanakan sehari sebelum acara pernikahan.

Setelah acara seserahan pada malam harinya dilaksanakan ngeuyeuk seureuh. Keesokan harinya dilaksanakan upacara akad pernikahan (akad nikah). Kemudian berlanjut pada upacara sawer, nincak endog, buka pintu dan huap lingkung.

\section{Pelaksanaan Sebelum Upacara Pernikahan}

\section{a. Upacara Neundeun Omong}

Upacara neundeun omong merupakan langkah awal dalam proses perkawinan Sunda. Neundeun omong mempunyai arti "titip pesan" atau "mengadakan perjanjian". Upacara dilaksanakan setelah adanya saling mengenal antara calon pengantin pria dan calon pengantin wanita,

Dalam proses pelaksanaannya, biasanya orang tua jejaka datang berkunjung kepada orang tua gadis idamannya. Hal ini bisa dilakukan sendiri atau bisa mengutus orang lain yang dipercaya. Orang yang dipercaya biasanya orang yang dituakan atau pria sepuh yang memiliki kepandaian dalam berbicara dan sudah banyak mengetahui tentang adat dan tatakrama.

Jumlah orang yang datang biasanya hanya dua atau tiga orang saja. Begitu pula orang yang menerimanya cukup orang tua gadis yang didatangi. Tidak ada barang yang dibawa, baik orang yang akan meminang maupun yang menerima tidak melakukan persiapan yang berlebihan. Pelaksanaannya sederhana, biasanya tetangga pun kadang-kadang tidak tahu.

Dalam upacara neundeun omong ini, sifatnya tidak mengikat, karena dari kedua belah pihak belum sampai pada penetapan dan menjanjikan sesuatu, hanya sekadar rencana yang masih perlu dipertimbangkan lebih lanjut. Mungkin saja suatu saat salah satu pihak membatalkan karena alasan tertentu. Selama kurun neundeun omong, kedua belah pihak saling mengawasi gerak gerik, keadaan tingkah laku kedua anaknya, selain itu mereka pun biasanya saling bersilaturahmi dan anjangsana. Situasi dan pergaulan antara si jejaka dengan si gadis sangat terbatas, bagi mereka dianggap sebagai ujian pertama. Kedua belah pihak berusaha untuk tidak sampai terjadi sesuatu yang tidak menyenangkan, karena dalam kurun waktu neundeun omong ini, kedua orang tua kedua belah pihak sudah mulai memikirkan tentang rencana perkawinan nanti.

\section{b. Upacara Ngalamar \\ Ngalamar atau melamar} merupakan langkah kedua yang biasa dilaksanakan dalam adat perkawinan Sunda. Ngalamar ini, biasanya dilaksanakan setelah upacara neundeun omong yang jangka waktunya beberapa bulan saja. Biasanya pihak laki-laki memiliki peran penting untuk 
menentukan pelaksanaanya. Walaupun pada prinsipnya kesepakatan kedua belah pihak sangat diutamakan, karena akan menyangkut soal biaya dan bahkan untuk melangsungkan perkawinan nanti.

Dalam adat perkawinan orang Sunda, upacara ngalamar maknanya sama dengan kata nanyaan (meminang). Menurut adat kebiasaan masyarakat di Kabupaten Bandung, upacara ngalamar ini sudah tidak lagi membawa barang barang bawaan seperti daun sirih, pinang, kapur sirih, gula dan tembakau (kebiasaan adat perkawinan zaman dahulu). Ternyata kini sudah berubah, cukup dengan membawa makanan.

Dalam acara ngalamar ini, orang tua si jejaka atau utusannya bertanya tentang keberadaan gadis impian anaknya, apakah masih bebas dan tidak terikat oleh lelaki lain. Seandainya masih bebas, apakah rela atau tidak untuk dipersunting anaknya. Umumnya pada acara lamaran, bukan orang tua si jejaka, tetapi yang menyampaikan maksud tersebut, biasanya mengutus orang lain, walaupun keduanya sama-sama datang.

Sebelum pelaksanaan upacara ngalamar, jauh-jauh hari pihak lelaki, biasanya sudah memberi tahu kepada pihak orang tua wanita tentang acara lamaran ini. Hal ini dilakukan untuk memberi waktu melakukan persiapan di pihak orang tua wanita.

Dalam upacara pinangan atau ngalamar ini diperoleh beberapa hal, pertama orang tua, baik orang tua calon pengantin laki-laki maupun orang yang mewakili. Orang yang mewakili biasanya mengerti tentang tata cara adat istiadat dan memiliki kepandaian dalam berbicara. Kedua, orang-orang yang hadir. Dalam hal ini, orang-orang tersebut hanya sebagai tanda penguat atau saksi bilamana lamaran diterima. Ketiga adalah barang bawaan.

\section{c. Upacara Nyangcang}

Tunangan dalam bahasa sunda biasanya disebut papacangan. Dalam masa tunangan ini, pergaulan antara si calon pengantin laki-laki dan calon pengantin wanita agak diperlonggar, tetapi masih tetap dalam pengawasan orang tua dan tidak bebas. Hubungan mereka dijaga jangan sampai melanggar norma-norma susila, baik norma agama maupun norma yang berhubungan dengan adat istiadat.

Dalam masa tunangan ini, walaupun kedua belah pihak sudah sama-sama mengikat janji, tidak menutup kemungkinan pertunangan atau perjanjian diputuskan karena salah satu pihak melakukan pelanggaran atau kesan yang kurang baik, baik putus secara sepihak maupun atas kesepakatan kedua belah pihak.

Lamanya pertunangan tidak ditentukan, tetapi umumnya hanya beberapa bulan saja, lebih-lebih karena menurut adat orang tua yang mengatakan "pamali lila-lila papacangan", artinya terlarang untuk lama-lama bertunangan.

Untuk merencanakan ke jenjang pernikahan berdasarkan hasil kesepakatan antara kedua belah pihak, biasanya bergantung pada kesempatan dan persediaan biaya. Dalam pelaksanaannya yang harus memikirkan secara sunguh-sungguh adalah pihak orang tua wanita, sebab pelaksanaan perkawinan dilangsungkan di kediaman calon pengantin wanita dan menjadi tanggungan pihak wanita. Bahkan bila dilaksanakan hajatan secara besar-besaran akan memerlukan biaya besar, walaupun 
biasanya pihak calon pengantin laki-laki membantu.

\section{d. Upacara Narikan}

Narikan merupakan adat yang isinya membicarakan kepastian pelaksanaan perkawinan, baik hari, tanggal, maupun waktunya. Untuk mendapatkan hari, tanggal dan waktu tersebut, biasanya menggunakan perhitungan yang berdasarkan kepercayaan masyarakat setempat. Hal itu bertujuan agar rumah tangga bahagia, menurut pandangan mereka. Berdasarkan perhitungan ini biasanya disepakati oleh kedua belah pihak. Perhitungan yang dipakai mulai hari, tanggal, waktu (jam), sampai waktu pagi dan siangnya. Bulan yang dijadikan pedoman menggunakan bulan Islam, dan yang banyak dipakai biasanya bulan Zulhijjah. Bulan tersebut dalam bahasa Sunda disebut bulan rayagung merupakan bulan besar dan mulia.

Upacara narikan ini biasanya berakhir dengan kesepakatan kedua belah pihak. Kesepakatan ini menyangkut berbagai hal tentang perkawinan, bahkan sampai pada masalah siapa orang - orang yang harus diundang, jika sudah pada masalah terakhir tadi barulah kesepakatan dianggap sempurna. Masalah biaya biasanya tidak dirundingkan dalam upacara narikan ini, karena masalah biaya hanya ditanggung oleh pihak wanita.

\section{e. Upacara Seserahan}

Upacara adat seserahan bermakna penyerahan atau menyerahkan, dalam upacara ini seserahan artinya menyerahkan atau memasrahkan calon pengantin laki-laki kepada calon orang tua dari calon pengantin perempuan, untuk kemudian dinikahkan kepada calon pengantin perempuan. Upacara ini dilakukan satu atau dua hari sebelum hari pernikahan dan biasanya dilakukan pada petang hari. Sementara itu di rumah orang tua perempuan sudah terlihat kesibukan untuk menyambut upacara seserahan ini. Keadaan rumah serba bersih serta dihias sedemikian rupa, sehingga nampak indah dilihatnya. Makanan dan minuman dipersiapkan untuk menyambut para tamu yang datang mengantar bakal menantunya. Tentang ragam dan nilai yang dipersiapkan oleh orang tua pihak mempelai pengantin perempuan bergantung pada kemampuannya. Dalam keadaan mewah dan meriah tentu akan lebih membanggakan hati kedua belah pihak. Keluarga dan kerabat dekat diundang untuk menyaksikan dan memeriahkan upacara seserahan ini.

Pada saat yang telah ditentukan terlebih dahulu serta telah diperbincangkan dengan orang tua mempelai perempuan, maka berangkatlah rombongan orang tua mempelai lakilaki. Apabila rumah mereka berdekatan, perjalanan dilakukan dengan berjalan kaki. Akan tetapi kalau jaraknya jauh, perjalanan dilakukan dengan menggunakan kendaraan, dan beberapa meter lagi menuju rumah mempelai perempuan rombongan turun. Waktu berjalan calon mempelai laki-laki berada di muka berdampingan dengan orang tuanya. Sementara itu di belakang mereka iringan keluarga serta handai taulan yang membawa serta barang-barang (bingkisan) untuk mempelai pengantin perempuan. Makin banyak orang yang ikut serta dalam rombongan makin besar hati kedua belah pihak. 


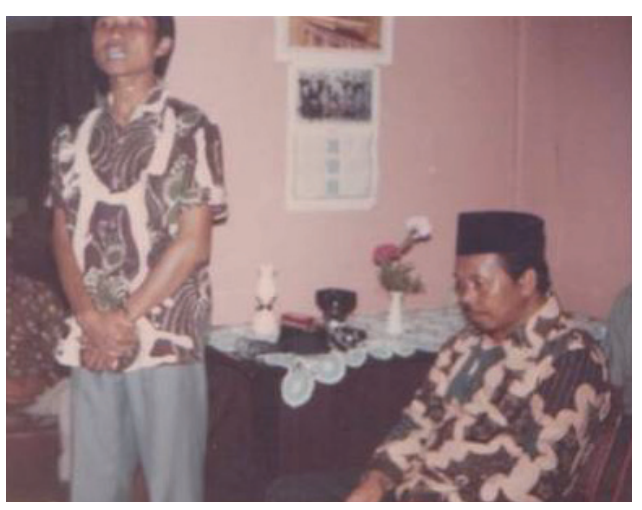

Gambar 1. Pada saat seserahan

Tentang banyak serta nilai dari barang-barang yang dibawa bergantung pada kemampuan pihak mempelai lakilaki. Biasanya barang-barang itu berupa uang, pakaian perempuan, perhiasanperhiasan seperti: gelang, kalung, cincin, serta keperluan wanita lainnya. Ada juga yang membawa alat-alat rumah tangga seperti: tempat tidur lengkap dengan kasur dan bantalnya, tempat pakaian. Demikian juga dengan alat-alat dapur seperti: dandang, kukusan, bakul, dulang, tampah, piring, gelas, cangkir, kompor, dan sebagainya yang dimaksudkan bilamana mereka sudah memiliki rumah bisa langsung dipergunakan.

Selain barang-barang di atas terkadang ada juga yang menambahkan dengan: sirih, pinang, kue-kue, beras, ayam, kambing, buah-buahan, kayu bakar, dan sapi. Setibanya di rumah calon besan, rombongan mempelai lakilaki dielu-elukan dengan gembira dan dipersilakan duduk secara terhormat oleh tuan rumah sekeluarga serta para tamu undangan. Iringan tamu duduk berhadaphadapan dengan pihak tuan rumah serta tamu lainnya. Barang bingkisan disimpan di tengah-tengah di hadapan hadirin. Setelah keadaan telah tenang, tidak menunggu lama biasanya pihak tamu memulai angkat bicara, baik orang tua mempelai pengantin laki-laki itu sendiri maupun perwakilannya. Seandainya dalam seserahan itu orang tua mempelai pengantin laki-laki mewakilkan kepada orang lain, maka wakil itu memohon maaf atas kedatanggannya yang mungkin menyusahkan tuan rumah. Ia pun mengucapkan terima kasih atas penerimaan yang sangat mengesankan, kemudian ia mengucapkan kata penyerahannya.

Setelah kata sambutan dari pihak tamu, sekarang bagian pihak tuan tumah yang memberikan kata sambutan. Sambutan bisa langsung oleh orang tua dari mempelai perempuan atau juga bisa diwakilkan.

Sambutan tersebut ditutup dengan doa keselamatan. Setelah itu lalu membuka barang bawaan dari mempelai laki-laki untuk diperlihatkan isinya kepada semua yang hadir.

Usai acara orang tua calon mempelai pengantin laki-laki pulang bersama-samadenganyangmengantarnya tadi, sedangkan calon pengantin lakilakinya tinggal di rumah bakal mertuanya. Adapun tidurnya kadang-kadang dirumah lain atau juga di rumah calon mertuannya tetapi ia belum diperbolehkan campur gaul "berhubungan" dengan mempelai pengantin perempuan.

\section{f. Upacara Ngeuyeuk Seureuh}

Kata ngeuyeuk asal katanya heuyeuk. Kata tersebut mempunyai dua pengertian, yaitu sama dengan mengatur atau mengurus atau mengerjakan. Misalnya: ngaheuyeuk nagara artinya mengurus negara, ngeuyeuk pare yang artinya mengerjakan padi supaya butirnya lepas. Adapun ngeuyeuk seureuh artinya 
mengerjakan dan mengatur sirih serta mengait-ngaitkannya.

Waktu untuk melakukan upacara ngeuyeuk seureuh adalah di petang hari, sehari sebelum hari penikahan. Dalam pelaksanaannya, dipimpin oleh seorang wanita yang telah berumur yang ahli dalam bidang upacara tersebut. Ia dibantu oleh seorang laki-laki yang telah berumur juga, yang bertugas membacakan doa. Banyaknya wanita yang menghadiri dalam pelaksanaan upacara tersebut biasanya berjumlah kelipatan 7. Pengambilan angka tujuh tersebut karena angka tersebut dianggap baik.

Dalam upacara tersebut tidak diperbolehkan dihadiri wanita yang belum menikah atau yang belum cukup umurnya, sudah beberapa kali menikah, dan juga wanita yang tidak pernah datang bulan (balangantrang). Hal itu disebabkan mereka dianggap bisa membawa pengaruh negatif, baik kepada kedua mempelai maupun kepada yang mengikuti upacara itu sendiri, dan yang paling ditakutkan adalah sifat-sifat buruk dari orang itu menular atau juga bisa mengakibatkan "jomblo" (sulit memperoleh jodoh).

Untuk laki-laki yang dilarang hadir hanya laki-laki yang belum dewasa atau belum cukup umur. Dalam pelaksanaannya, mereka duduk beralaskan tikar, tidak disediakan kursi, termasuk untuk kedua calon pengantin yang harus ikut hadir. Tempat yang dipergunakan untuk upacara ini biasanya dipergunakan tengah rumah yang cukup luas. Adapun peralatan atau syarat-syarat yang dipergunakan dalam upacara ini adalah: sirih beranting, setandan buah pinang muda, gambir, kapur sirih, tembakau, mayang pinang (ini biasanya bingkisan dari pihak laki-laki waktu seserahan).

Bahan-bahan yang akan digunakan dalam upacara, semuanya disatukan kecuali ajug (pelita). Mula-mula jinem atau penggantinya kain poleng (semacam pelekat) dibentangkan dan diletakkan paling bawah, benda-benda lainnya ditaruh di atasnya, ditutup dengan kain putih (kain kafan). Perempuanperempuan yang akan melakukan upacara, semua duduk mengelilingi tumpukan syarat-syarat yang akan digunakan dalam upacara. Kedua calon mempelai ikut duduk bersanding. Bakal mempelai wanita telah dikerik yaitu sebagian rambut yang ada dikeningnya dipotong termasuk bagian alisnya juga sedikit ikut dipotong.

Setelah berbagai keperluan dan pelaksanaan siap, yang akan memimpin upacara (ketua) membuka acara dengan diawali ijab kabul. Mula-mula ketua meminta permohonan maaf mengenai pelaksanaan upacara. Dalam uraiannya beliau menyampaikan mengenai tugas yang diembannya, bahwa tugas tersebut merupakan permintaan dari orang tua calon mempelai wanita. Kepada semua yang hadir diminta bantuan untuk mengikutiacara ini dengan penuh khidmat agar terhindar dari hal-hal yang dapat mengganggu jalannya upacara . Serta mengajak pula berdoa kepada Allah SWT agar kedua mempelai mendapat rahmat, serta dapat membangun rumah tangga yang sakinah, mawadah, warohmah.

Sehabis itu dimintanya orang tua dari calon mempelai laki-laki untuk membakar kemenyan pada tempat yang sudah disediakan (parukuyan) atau pedupaan. Selanjutnya parukuyan tersebut ia angkat lalu diputarkan kepada hadirin yang hadir untuk secara giliran 
membakar sedikit kemenyan atau dupa. Terakhir baru ia membaca doa selamat.

Selesai melaksanakan doa bersama, ketua menyalakan ketujuh sumbu pelita sampai menyala semuanya, dan memberi penjelasan yang ditujukan kepada kedua calon pengantin, bahwa ketujuh sumbu itu melambangkan jumlah hari dalam seminggu yang setiap harinya selalu mengelilingi matahari. Hal itu merupakan isyarat kepada kedua mempelai agar nanti setelah menikah mereka harus selalu bererus terang jangan sampai ada yang ditutup-tutupi. Selain itu juga mereka harus bisa mengamalkan kebaikan kepada orang lain dengan jalan memberikan penerangan. Namun jangan bersifat "ilmu ajug", yang artinya sinar api pelita hanya dapat menerangi orang lain, tidak bisa menerangi dirinya sendiri. Dengan kata lain berarti memberi petunjuk kebaikan kepada orang lain tetapi diri sendiri berkelakuan buruk.

Ketua atau yang dituakan mengangkat kain kafan dan tikar tutup benda-benda upacara, serta menjelaskan bahwa: bagaimanapun keadaan manusia, laki-laki, perempuan, kaya, miskin, pembesar, rendahan dan sebagainya, akhirnya pada suatu saat hanya dibungkus dengan kain kafan dan tikar yang dibawa ke kuburan. Oleh karena itu selama kita masih hidup harus insyaf, serta taat kepada ajaran-ajaran agama, dan juga mematuhi segala perintah dan laranganNya.

Selanjutnya ranting-ranting sirih dibagikan kepada masing-masing peserta untuk memulai ngeuyeuk. Caranya: "perut" daun sirih dari ranting yang satu diletakkan dengan "perut" daun sirih dari satu ranting yang lain. Kedua tepinya digulung sehingga keduanya bertemu di tengah-tengah di bagian induk tulang daun, lalu diikat dengan rambu (benang tenun). Bentuk serupa ini disebut lungkun. Selesai membuat lungkun, disatukan lagi dua helai sirih dari masing-masing ranting seperti tadi. Salah satu bagian belakangnya dioles dengan kapur sirih basah, dibumbui gambir sirih halus dan irisan pinang, hingga memadai untuk dikunyah. Dilipat dua atau tiga lipatan ke samping sehingga membentuk lipatan panjang, bagian bawah lipatan dipintal ke atas ujungnya dilipat ke dalam sehingga berbentuk susuh atau kerucut dan ini disebut tektek. Pada bagian atasnya terdapat rongga, rongga ini diisi tembakau kasar sehingga sepintas menyerupai rongga berbulu. Perihal rumpun sirih dan tektek, artinya kedua helai daun sirih yang berlainan ranting menunjukkan dua jenis insan yang berlainan asal tempat tinggalnya, intinya bukan teman serumah atau saudara kandung.

Perut keduanya ditempelkan atau dipertemukan artinya dinikahkan. Kedua itu berlainan jenis, digambarkan oleh serangkai daun yang berlipat, dipintal sehingga menjadi tektek yang bagian di rongganya diselipkan tembakau, yang melambangkan perempuan. Hal itu mengambarkan seolah-olah bagian vitalitas perempuan. Adapun rangkap yang digulung disebut lungkun, diibaratkan bagian vitalitas anggota badan untuk laki-laki. Lungkun diikat dengan rambut, maksudnya melambangkan untuk mengikat laki-laki (suami) adalah wanita (istri). Itulah sebabnya maka sebagai pengikat haruslah rambut, sebab rambut adalah hasil pekerjaan perempuan (bertenun). Rambut merupakan bagian yang ada pada badan manusia yang kuat. Jadi, istri sebagai pengikat haruslah kuat, tabah, ulet, dan waspada. 
Orang makan sirih pun harus menjadi teladan; artinya lambat-laun, sarinya ditelan, ampasnya dibuang. Dalam segala langkah harus dipikirkan, dipertimbangkan masak-masak. Hal yang baik diambil dan yang buruk dibuang sesuai dengan peribahasa "dibeuweung diutahkeun", di kunyah dimuntahkan.

Tektek juga melambangkan kerukunan, sebab bilamana isi tektek tidak seimbang akan berakibat buruk kepada si pemakan sirih, setidak-tidaknya tidak akan merasa nikmat.

Sementara ketua memberi penjelasan kepada kedua calon mempelai, ketua terus menerangkan perlambang atau simbol dari benda-benda yang dipergunakan dalam upacara ngeuyeuk seureuh tersebut.

Setandan pinang muda, melambangkan keberadaan makhluk Tuhan yang harus hidup rukun dan tertib. Hal ini harus menjadi contoh keteladan, bahwa manusia harus hidup rukun, dengan siapa saja, lebih-lebih sebagai suami istri.

Mayang (bunga pohon pinang) yang masih terbungkus, melambangkan seorang gadis yang masih utuh kegadisannya (perawan), lalu dipecahkan olehcalonmempelailaki-laki.Haltersebut melambangkan untuk seorang gadis yang dikawini harus dapat melaksanakan kewajibannya sebagai seorang istri, serta menginsyafi bahwa dengan jalan ini ia harus mengembangkan keturunan.

Tunjangan sebagai petunjuk kepada yang bersuami istri harus saling menunjang agar rumah tangga aman sejahtera, rukun dan makmur. Lebihlebih lagi seorang suami, ia harus bersifat seperti tunjangan tempat menunjang kaki perempuan (penenun) hingga duduknya.
Telur ayam mentah bersamasama dipecahkan dengan elekan setelah pada upacara nincak endog. Bedanya elekan dipecahkan dengan kaki kanan sedang telur diinjak sampai pecah dengan kaki kiri, memberi isyarat bahwa pengantin perempuan bersedia dirusak, dipecahkan kegadisannya.Telur yang telah dipecahkan memberi pengertian, bahwa setelah telur itu pecah tampak isinya berupa lendir yang menjijikkan. Padahal benda setengah cair itu adalah bakal jadi manusia. Sehubungan dengan itu, sebagai insan manusia tidak boleh sombong.

\section{Pelaksanaan Upacara Pernikahan}

Upacara akad nikah atau walimah adalah upacara adat perkawinan yang pokok, baik secara adat maupun secara agama Islam. Sebab satu dan lain hal upacara-upacara lain terpaksa diabaikan (tidak dijalankan), maka upacara akad nikah ini sekali-kali tidak boleh tidak, harus dijalankan. Kalau upacara ini tidak dilaksanakan berarti perkawinannya dianggap tidak sah.

Pelaksanaannya adalah berdasarkan keharusan agama. Oleh karena umumnya orang Sunda memeluk agama Islam, maka dalam uraian ini diutamakan hanyalah berdasarkan aturanaturan agama Islam. Akan tetapi sifat pokok perkawinan sama dengan sifat perkawinan sebelum ada pengaruh Islam: mereka kawin atas kemauan sendiri, dengan persetujuan kedua orang tua masing-masing. Mereka dikawinkan oleh orang tua perempuan melalui "penghulu" mereka. Orang bisa dikawinkan hanya bilamana telah memenuhi ketentuan- 
ketentuan yang telah digariskan dan bersendikan agama Islam serta adat.

Syarat-syarat termaksud antara lain: perkawinan dilangsungkan atas dasar keinginan kedua calon mempelai, tanpa ada paksaan. Harus ada wali, ialah ayah calon mempelai perempuan, atau wakilnya (pengganti) yang sah, dan terdapat dua orang saksi (sekurangkurangnya). Calon mempelai adalah benar-benar seorang wanita dan lakilaki dimana umur kedua belah pihak memang sudah cukup untuk kawin, dan lain sebagainya.

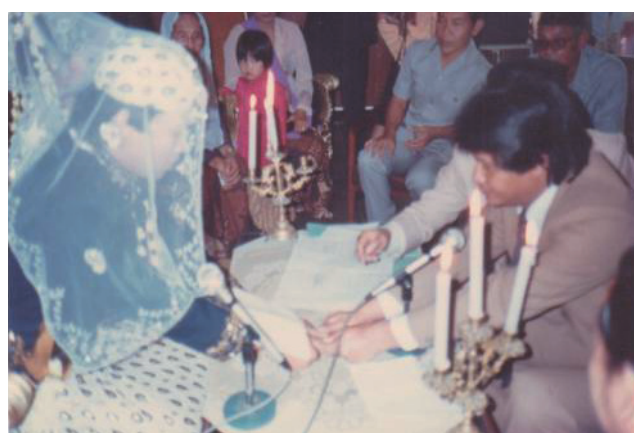

Gambar 2. Pada saat akad nikah

Selanjutnya yang memimpin pelaksanaan akad nikah adalah seorang penghulu atau naib, yaitu pejabat Kantor Urusan Agama. Ia didampingi oleh bawahannya yang berjabatan lebih dari petugas-petugas lainnya. Biasanya paling banyak hanya tiga orang. Tugas pokok, di samping memberi petunjuk-petunjuk atau petuah-petuah berlandaskan keagamaan, mencatat nama pengantin di dalam buku.

Tempat untuk melangsungkan walimah adalah di masjid yang di antaranya memang sudah disediakan untuk itu. Akan tetapi untuk yang menginginkan, di rumah sendiri pun bisa. Hanya biayanya tentu akan lebih besar berhubung dengan ongkos jalan dan lainlainnya, Kepala Kantor Urusan Agama yang bersangkutan yang menetapkan.

Pada saat yang telah ditentukan terlebih dahulu dan biasanya di pagi hari, kedua mempelai berangkat bersamasama menuju masjid. Mereka diantar oleh wali, orang-orang tua dan keluarga kedua belah pihak. Pakaian untuk pergi ke masjid sekadar bagus saja bukan pakaian khusus mempelai yang istimewa. Ada kalanya mempelai wanita tidak turut ke masjid, hanya mempelai laki-laki saja jika perjalanan yang harus ditempuh agak jauh dan tidak ada kendaraan. Hal itu dapat dilakukan karena terlebih dahulu telah diperbincangkan dengan penghulu atau naib yang akan mengurus perkawinan tersebut. Jadi, hal itu dapat dilakukan setelah mendapat persetujuan, dengan kata lain memang dapat dipertanggungjawabkan.

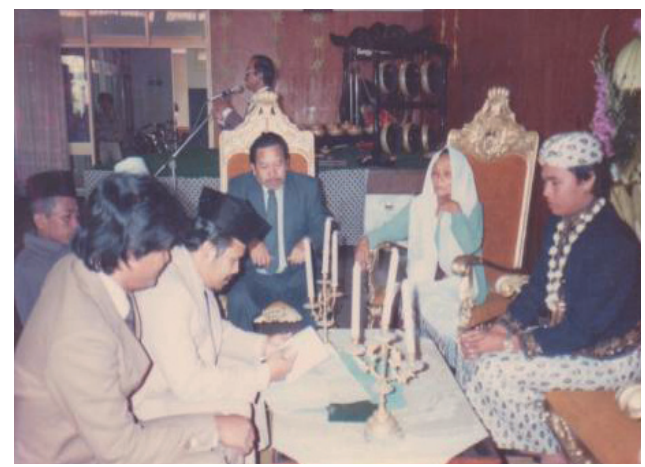

Gambar 3. Pada saat akad nikah

Tiba di masjid, kedua mempelai duduk bersanding diapit oleh orang tua mereka. Mereka duduk berhadaphadapan dengan penghulu dan di kanankirinya didampingi dua orang saksi, yang terdiri atas lebe dan yang lainnya, biasanya pegawai dari Kantor Urusan Agama atau orang lain yang ditunjuk oleh 
kedua orang tua mempelai. Keluarga dan pengantar lainnya duduk berkeliling.

Orang-orang melangsungkan akad nikah di masjid terutama karena masjid adalah pusat kegiatan keagamaan, sekaligus mengikuti tradisi lama. Adapun yang mengawinkan harus wali dari mempelai perempuan sendiri, tetapi ia boleh mewakilkan kepada penghulu. Cara terakhir adalah yang paling banyak dilakukan. Bilamana si Wali ingin mengawinkan sendiri, terlebih dahulu oleh penghulu diberi petunjuk untuk melakukannya, yang prakteknya sama dengan mengawinkan oleh penghulu itu sendiri.

Setelah proses akad nikah, mereka menuju rumah. Setiba di rumah, mereka disambut dengan meriah oleh seisi rumah beserta keluarga kedua belah pihak, juga para tamu yang meluangkan waktu datang pada saat itu. Biasanya mereka yang rumahnya berdekatan atau sangat akrab kepada salah satu pihak. Tamutamu lain diundang pada kesempatan lain yang lebih meriah. Setelah memberi salam, maka diadakanlah selamatan atau kenduri tanda kegembiraan, sekaligus sebagai acara memohon perlindungan kepada Tuhan YME dan para leluhur dari kedua belah pihak agar keluarga baru dikaruniai keselamatan dan kebahagiaan hidup.

Setelah akad nikah selesai, bahkan juga sebelumnya, kepada para undangan biasanya sudah diberitahukan tentang akan diadakannya arak-arakan, yang dalam bahasa Sunda disebut iring-iringan atau helaran. Menjelang kedua mempelai berpakaian dan dihias, pengantin pria biasanya dijauhkan dari rumah mertuanya. Kemudian di tempat masing-masing kedua mempelai dihias dan didandani dengan pakaian pengantin oleh orang yang ahli mendandani dan menghias pengantin.

Pakaian pengantin laki-laki terdiri atas ikat kepala disebut iket atau totopang, sedang golongan menengah ke atas memakai bendo atau orang Jawa menyebutnya blangkon. Bajunya potongan jas tertutup; orang berpangkat atau berada, potongan jas buka memakai kemeja putih berdasi melintang (kupukupu), hitam atau putih. Jas berwarna hitam atau putih, dan kadang-kadang memakai rompi. Pada leher dikalungkan untaian bunga melati atau bunga tanjung. Kemudian di pinggang sering pula diselipkan sebilah keris yang juga memakai untaian bunga. Pakaian bagian bawah memakai kain panjang yang dilipat, namanya lamban. Corak batiknya sama dengan bendo (ikat kepala = tutup kepala), pada umumnya disebut batik uwit, alas kaki berupa selop atau sandal dari kulit berwarna hitam atau coklat. Zaman sekarang banyak kelihatan yang memakai celana panjang (pantalon) dan sepatu.

Pakaian pengantin perempuan. Sebelum didandani, terlebih dahulu mempelai perempuan dimandikan dengan air bunga-bungaan, lengkap dengan mantera (jampinya)-nya, oleh "orang tua" juru hias. Lalu seluruh tubuhnya diusap dengan lulur, berupa bedak badan tradisional yang berbau wangi, berwarna kuning (atal). Rambut di keningnya yang sudah dipotong seperlunya waktu akan ngaheuyeuk seureuh, alis mata dan cambangnya diatur (ditata), mukanya dibedaki, pipi dan bibirnya diwarnai menurut keserasian dengan warna kulit mempelai.

Rambut pengantin perempuan disanggul dan dibentuk sedemikian rupa serta dihias dengan bunga-bungaan baik 
asli maupun tiruan. Warna baju kebaya belakangan berwarna putih, tetapi warna lain pun banyak juga dijumpai. Biasanya warna yang ringan seperti kekuningkuningan, kebiru-biruan, dan sebagainya. Kainnya adalah kain panjang yang sama betul warna dan corak batiknya dengan kain panjang yang dipakai oleh pengantin pria. Alas kakinya berupa selop, warna dan bentuknya tidak ditentukan.

Sementara kedua mempelai dihias dan didandani, kendaraan untuk keduanya dipersiapkan. Begitu pula aneka bunyi-bunyian untuk memeriahkan arak-arakan, serta orang-orang yang akan mendampingi dan mengiringi mereka. Macam kendaraan untuk pengantin bergantung pada kemampuan dan kedudukan orang tua pengantin, terutama pengantin wanita karena ialah yang mempunyai kenduri atau pesta itu.

Selesai mempelai pria dihias dan didandani, menurut waktu yang sudah diatur dan ditetapkan terlebih dahulu, dinaikanlah ia ke atas kendaraan atau usungan yang telah disiapkan baginya. Pada saat yang telah ditentukan, berangkatlah iringan mempelai pria menuju rumah mempelai wanita.

Mempelai wanita dengan segala kelengkapannya yang tidak ikut ke tempat mempelai pria, telah disiapkan untuk ikut bersama-sama berarak-arakan. Setibanya iringan ke tempat tujuan, dinaikkanlah mempelai wanita ke atas kendaraan atau usungan mempelai pria untuk duduk bersanding. Sesudah segala sesuatunya siap, maka dibunyikanlah segala bunyi-bunyian serta arak-arakan mulai bergerak maju. Sementara itu muka usungan kedua mempelai, berjalan barisan kehormatan atau pengamanan, baik sambil membunyikan bunyi-bunyian maupun tidak.

\section{Upacara Sesudah Perkawinan}

\section{a. Upacara Sawer (nyawer)}

Sawer atau nyawer asal katanya awer, mempunyai arti air jatuh menciprat, sesuai dengan praktek juru sawer yang menabur-naburkan perlengkapan nyawer, seolah-olah menciprat-cipratkan air kepada kedua mempelai wanita dan pria serta semua yang ikut menyaksikan di sekelilingnya. Akan tetapi besar pula kemungkinannya bahwa perilaku adat ini disebut nyawer oleh karena dilaksanakan di panyaweran atau taeuran, yang dalam bahasa Indonesia disebut cucuran atap.

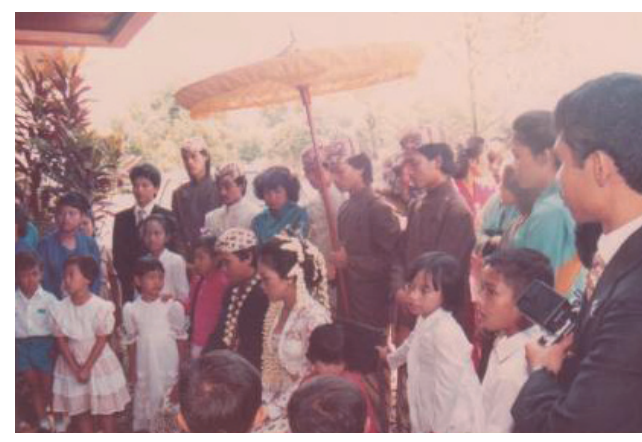

Gambar 4. Pada saat acara sawer

Adapun perlengkapan untuk nyawer terdiri atas beras putih, irisan kunir tipis, uang kecil (receh), yang jumlahnya menurut keinginan, dan biasanya uang logam agar mudah dilemparkan (ditaburkan) bersama bungabungaan serta dua buah tektek (gulungan daun sirih berbentuk kerucut yang di dalamnya berisi ramuan sirih seperti kapur, gambir, pinang dan sebagainya). Semua perlengkapan tersebut dicampur aduk menjadi satu dan ditaruh di dalam sebuah bokor yang terbuat dari perak atau kuningan (perunggu). Juru sawer menaburkan isi bokor tadi sebagai selingan dari syair yang dinyanyikan 
olehnya sendiri. Sebenarnya pokok dari upacara ini ialah isi atau maksud dari syairnya itu. Adapun inti dari syairnya itu adalah sebagai berikut: minta maaf dan izin kepada hadirin untuk melangsungkan sawer; menasihati mempelai wanita untuk mengabdikan diri kepada suami secara tulus dan ikhlas sepenuh hati, begitu pun sebaliknya suami kepada isterinya; kedua belah pihak harus saling mencintai, menyayangi, dan membela, bahkan bila salah seorang sedang marahmarah, yang seorang harus mengalah untuk menghindarkan percekcokan yang lebih lanjut. Pihak yang satu harus dapat menghibur pihak yang satunya lagi bilamana terjadi kemurungan. Demikian pula kepada tetangga, handai taulan harus baik . Isi syair pun mendoakan agar kedua mempelai mendapat rakhmat Ilahi sehingga memperoleh kesejahteraan dan kebahagian dalam membina rumah tangganya, hidup rukun sampai akhir hayat.

Upacara nyawer dilangsungkan di depan rumah di bawah cucuran atap. Dalam bahasa Sunda cucuran atap ini disebut panyaweran yang artinya tempat sawer, tempat jatuhnya air hujan dari atap rumah menciprat ke segala arah.

\section{b. Upacara Nincak Endog}

Selesai upacara nyawer kedua mempelai wanita dan pria dibimbing maju mendekati rumah tangga. Di sana telah disiapkan: sebuah ajug yang di atasnya terletak sebuah pelita minyak kelapa bersumbu 7 (dewasa ini diganti dengan lilin karena sulitnya mendapatkan ajug berpelita, yang terbuat dari tanah liat atau perunggu); seikat harupat (sagar enau) berisikan 7 batang; sebuah tunjangan ataupun barera yang keduaduanya merupakan alat tenun tradisional, bagian tengahnya diikat dengan sehelai kain tenun poleng; sebuah elekan yang juga merupakan alat tenun tradisional berupa seruas bambu kecil tidak berbuku; sebuah telur ayam mentah; sebuah kendi dari tanah berisi air bening; sebuah batu pipisan. Lilin dinyalakan. Mempelai wanita membakar harupat yang seikat dengan nyala api pelita. Setelah padam selanjutnya dibuang atau dibiarkan sampai habis jadi abu. Hal tersebut harus dijadikan lambang oleh kedua mempelai, bahwa sifat-sifat yang "getas harupaten" harus ditumpas demi ketentraman rumah tangga, karena sifat itu pada manusia adalah lekas marah atau pemberang. Kalau mempergunakan ajug harus diambil cerminnya, bahwa mempelai janganlah bersifat "elmu ajug". Artinya jangan pandai menasihati orang lain sedangkan dia sendiri tidak melaksanakannya.

Menyusul kemudian mempelai pria menginjakkan kaki kanannya dengan kuat di atas elekan yang telah ditaruh di sebelah kiri elekan tadi, hingga pecah. Kedua kaki yang telah dipergunakan memecahkan benda tadi selanjutnya dipijakkan di atas batu pipisan. Kemudian langsung dicuci oleh mempelai wanita dengan air kendi yang telah tersedia. Kendi dipecahkan sehabis dipakai menyatakan kepuasan hati. Berpijak di batu pipisan melambangkan ketetapan hati, lurus dan kokoh, karena batu pipisan di samping berat juga permukaan atas dan bawahnya rata. Setelah selesai menghempaskan kendi, mempelai lakilaki berjalan sambil tangannya dituntun oleh mempelai perempuan melangkah menaiki tangga rumah yang terlebih dahulu melangkahi tunjangan atau barera (alat tenun). 


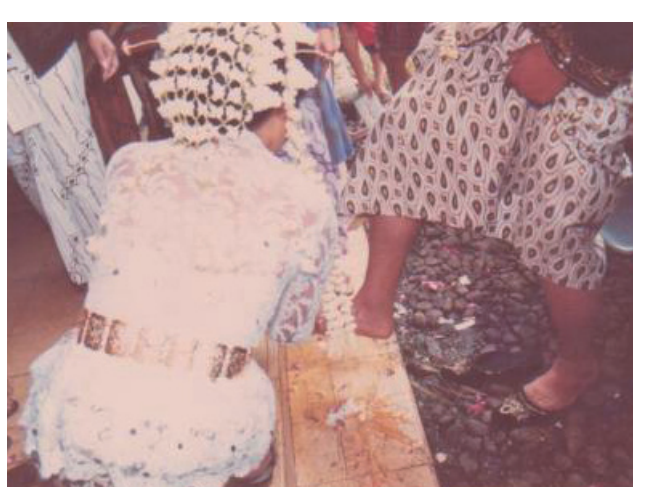

Gambar 5.

Pada saat upacara nincak endog

Kedua mempelai terus bergandengan naik ke rumah mendekati pintu. Sampai di muka pintu mempelai wanita masuk ke dalam rumah, sementara mempelai pria ditinggal di luar. Makna dari proses tersebut, bahwa walaupun akad nikah dan upacara lain sudah dilaksanakan, ia masih harus menjalani ujian tentang kebenarannya beragama Islam. Setelah mempelai wanita mengucapkan syahadat, maka pintu pun dibuka, sang pria disambut oleh isterinya dengan sembah sungkem dan berjalan menuju ke tempat huap lingkung.

\section{c. Upacara Huap Lingkung}

Huap lingkung terdiri dari atas dua kata yaitu huap yang berarti suap, dan lingkung, akar kata Indonesia melingkungi, mengurung. Perlengkapan yang disiapkan dalam upacara ini pada pokoknya nasi kuning, bekakak ayam ialah panggang ayam yang bagian dadanya dibelah dua, dan air minum. Kedua mempelai bersanding, yang wanita di sebelah kiri pria. Mula-mula keduanya disuruh memegang bekakak ayam yang hanya satu itu, masingmasing di sisi kanan dan kirinya. Mereka saling menarik bekakak ayam tersebut hingga terbelah menjadi dua. Siapa yang mendapat bagian terbesar di tangannya, disebutkan ialah yang akan paling banyak memperoleh rejeki di antara keduanya. Hal itu juga mengandung makna bahwa bagi orang yang bersuami isteri memberi tidak terbatas, dengan tulus dan ikhlas sepenuh hati.

Sehabis upacara huap lingkung, kedua mempelai dipersilakan berdiri di pelaminan diapit oleh kedua orang tua masing-masing untuk menerima para tamu.

\section{PENUTUP}

Upacara adat perkawinan Sunda merupakan salah satu budaya yang sampai saat ini keberadaanya masih tetap dipertahankan oleh masyarakat pemiliknya, dalam hal ini masyarakat di Kabupaten Bandung. Dalam upacara adat perkawinan ini terdiri atas serangkaian acara yang satu sama lainnya sangat berkaitan. Rangkaian acara tersebut bisa dibagi dalam tiga bagian kegiatan, yaitu; pertama kegiatan sebelum upacara perkawinan, kedua upacara pelaksanaan perkawinan, dan yang ketiga upacara setelah perkawinan. Kegiatan upacara sebelum acara perkawinan terdiri atas: nenden omong (titip pesan), ngalamar (melamar), tunangan, narikan (memastikan waktu pelaksanaan), seserahan (serah terima), dan ngeuyeuk seureuh. Kegiatan pelaksanaan perkawinan terdiri atas akad nikah dan sungkem. Adapun kegiatan sesudah perkawinan terdiri atas nyawer, nincak endog dan huap lingkung.

Simbol dan makna yang ada dan digunakan dalam kegiatan upacara adat perkawinan ini memiliki nilai yang masih dianggap cukup tinggi oleh 
masyarakat di Kabupaten Bandung. Hal itu tampak dari sebagian masyarakat yang masih melaksanakan upacara adat perkawinan ini dengan segala syarat yang diharuskan dalam pelaksanaan kegiatan upacara tersebut. Mulai dari kegiatan pranikah sampai pasca nikah. Simbol-simbol tersebut hanya diartikan sebagai simbol yang bernuansa budaya yang kadang-kadang hanya dijadikan sarana kemeriahan pesta upacara adat perkawinan.

\section{DAFTAR PUSTAKA}

Departemen P \& K. 1978.

Petunjuk Pelaksanaan Adat dan

Upacara Perkawinan, Jakarta: PP \& PPKD.

Departemen P \& K, 1982.

Adat dan Upacara Perkawinan Daerah Jawa Barat. Jakarta: Proyek Inventarisasi dan Dokumentasi.

Departemen P \& K, 1983.

Upacara Tradisional Daerah Jawa Barat. Jakarta: Proyek Inventarisasi dan Dokumentasi.
Modana. Bandung: PT. Mangle Panglipur.

LBSS. 1982.

Kamus Umum Basa Sunda di Pasundan, Bandung: Sumur Bandung.

Suganda, Prawira 1964.

Upacara Adat di Pasundan, Bandung: Sumur Bandung.

Poerwadarminta, WJS. 1952.

Kamus Umum Basa Indonesia. Jakarta: Balai Pustaka. 